\title{
Treatment of acute gonorrhoea with a single oral dose of rifampicin
}

\author{
JYTTE PANDURO \\ Rudolph Bergh's Hospital, 4760 Vordingborg, Denmark
}

Rifampicin (Rimactane $@$ (CIBA)) is a semi-synthetic antibiotic (3-(4-methyl-1-piperazinyl-iminomethyl)rifamycin SV), derived from the rifamycins, which are produced by Streptomyces mediterranei. Rifampicin differs from other rifamycins in that it is active when taken by mouth, has a wider spectrum of action, and is eliminated more slowly. It is active against Gram-positive bacteria, particularly streptococci, against Gram-negative bacteria, including gonococci, and against Mycobacterium tuberculosis. Its activity is presumably mediated by the fact that rifampicin, in vitro as well as in vivo, prevents the formation of messenger-RNA, since it inhibits RNA-polymerase by forming a stable complex with it. DNA-polymerase is not affected (Hartmann, Honikel, Knüsel, and Nuesch, 1967).

Rifampicin does not appear to be toxic to human enzymes (Wehrli, Nuesch, Knüsel, and Staehelin, 1968). The most recent experimental studies have shown that rifampicin inhibits the growth of certain pox- and adeno-viruses (Heller, Argaman, Levy, and Goldblum, 1969; Subak-Sharpe, Timbury, and Williams, 1969). Furthermore, rifampicin is said to inhibit TRIC-agents (Becker and Zakay-Rones, 1969); but this finding is not of clinical significance as the therapeutic concentrations which are necessary would have a toxic effect on human cells during growth.

After administration the maximum serum concentration of rifampicin is reached at 2 hours. With a single oral dose of $900 \mathrm{mg}$. a concentration of $27.2 \mu \mathrm{g} . / \mathrm{ml}$. is reached after 2 hours, and then falls to $15.44 \mu \mathrm{g} . / \mathrm{ml}$. after 8 hours, $8.33 \mu \mathrm{g} . / \mathrm{ml}$. after 12 hours, and $1.64 \mu \mathrm{g} . / \mathrm{ml}$. after 24 hours. For purposes of comparison it should be mentioned that the minimum inhibitory concentration for gonocosci is of the order of $0.02 \mu \mathrm{g} . / \mathrm{ml}$. (Lepetit Pharmaceuticals, 1968). The serum concentration is said to increase more rapidly and to reach a higher level if the preparation is taken on an empty stomach. The

Received for publication April 7, 1971 distribution is uniform in all the body tissues; it is excreted via the bile by the same mechanism as bilirubin, and, to a lesser degree, via the kidneys. Rifampicin is normally well tolerated, and sideeffects such as dyspepsia and allergic complaints are extremely rare. Rifampicin is intensely red-brown in colour, and stains the urine reddish-orange. Among the contraindications are icterus with delayed bilirubin excretion, and pregnancy during the first trimester.

The effect of a single dose of $900 \mathrm{mg}$. rifampicin on acute gonococcal infections has already been reported. Willcox, Morrison, and Cobbold (1970) found a cure rate of 89 per cent. in a series of 89 cases in men; Ciaula and Rantuccio (1968) treated 32 patients, of whom 31 were cured with a single dose of rifampicin, and the other with two doses of $900 \mathrm{mg}$. administered at an interval of 1 week. Califano and Tagliavini (1968) achieved a recovery rate of 95.5 per cent. in a series of 96 patients. Rifampicin in this dosage does not appear to affect Treponema pallidum nor to mask syphilitic infections: In three cases of primary and two of secondary syphilis, the titre of the serological tests rose after treatment (Fuga, 1968), and in a case reported by Arya, Rao, and Nnochiri (1971) a primary chancre developed 1 week after the administration of $900 \mathrm{mg}$. rifampicin and was dark-field positive 10 days after a second dose.

\section{Present investigation}

MATERIAL AND METHODS

A series was examined of 118 consecutive patients (76 men and 42 women) with gonorrhoea, who attended for the first time on all the odd days of the trial period. Each patient was given a single oral dose of $900 \mathrm{mg}$. rifampicin immediately the diagnosis had been made on the basis of microscopic examination of a methylene-blue stained urethral smear in the cases of men, and of urethral and cervical smears in women. Cultures were performed in all cases, and determination of antibiotic sensitivities was performed on 75 isolates, some from the trial group and some from the controls. 
The control group consisted of 113 patients with gonorrhoea, diagnosed by the same methods, who attended on all the even days of the trial period. All but two of these patients were given $1 \mathrm{~g}$. probenecid followed 30 minutes later by an injection of $5 \mathrm{~m}$.u. sodium penicillin G. (the standard penicillin-probenecid treatment); two last cases are not considered separately because there was no case of failure in the control group.)

\section{Results}

Table I shows that 36 women were followed up with three cultures and 62 men with two cultures at 1 week's interval after treatment. Twenty patients who failed to attend for follow-up examinations and four with negative results to cultures were excluded from the series. 78 were cured, six were considered to be re-infected, and in ten cases the treatment was considered to have failed. In these last cases, reinfection was discounted as the patients themselves denied such a possibility and the pattern of antibiotic sensitivities of the strains isolated before and after treatment remained similar. In the group initial and post-treatment isolates showed differences, a finding which was confirmed by admission of reexposure to infection in all cases. One case of reinfection was cured by a further dose of rifampicin, four by standard penicillin-probenecid treatment, and one by tetracycline. In two cases in which the initial rifampicin treatment failed, re-treatment at the first follow-up examination was successful. In one case, the second rifampicin treatment failed, but the infection was cured with penicillin and probenecid, as were the remaining seven cases in which rifampicin treatment was not repeated.

In 41 cases, treatment response was related to the time of the last meal before treatment. Table II shows that there is no indication that the degree of gastric filling affects the result of that treatment at the dose used.

With regard to side-effects, there was only one case of vomiting after administration of the dose; one was given streptomycin, and one tetracycline. (These with re-infections, the resistance patterns of the

TABLE II Results of treatment with rifampicin related to time of last meal

\begin{tabular}{|c|c|c|c|}
\hline Hours since last meal & $1-3$ & $3-5$ & $5+$ \\
\hline $\begin{array}{l}\text { No. treated } \\
\text { No. followed up }\end{array}$ & $\begin{array}{l}18 \\
17\end{array}$ & $\begin{array}{r}10 \\
8\end{array}$ & $\begin{array}{l}19 \\
16\end{array}$ \\
\hline $\begin{array}{l}\text { Failures: No. } \\
\text { Per cent. }\end{array}$ & $\begin{array}{l}\mathbf{0} \\
\mathbf{0}\end{array}$ & $\begin{array}{r}2 \\
25\end{array}$ & $\begin{array}{c}3 \\
18 \cdot 7\end{array}$ \\
\hline
\end{tabular}

this patient's infection was cured by one more dose $\vec{\sigma}$ of rifampicin taken at the first follow-up examination. There were no cases of allergic reactions.

Table I also shows that 88 patients in the control. group were followed-up after treatment. The rest were excluded from the series. 78 were cured primarily, eight were re-infected, two proved to have 0 had non-gonococcal urethritis. Thus, in this group. no case of gonorrhoea failed to respond to treatment. $\square$ During the trial period, 75 of the specimens col- $\mathbb{\mathbb { D }}$ lected from both groups were tested in the Neisseria Department of the State Serum Institute for sensitivity to penicillin, tetracycline, streptomycin, and rifampicin. Previous examinations by other investio $\vec{\theta}$ gators have shown a correlation between diminishe penicillin sensitivity and lessened sensitivity rifampicin (Phillips, Rimmer, Ridley, Lynn, an Warren, 1970), and also to other antibiotics - spiramycin, streptomycin, tetracycline, and erythromycin (Reyn and Bentzon, 1969). In the rresent series $\mathbb{D}$ there was a correlation between the minimum inhibition concentrations for rifampicin and penicillin, but this was of very slight degree though statistically significant.

\section{Discussion}

In the treatment of acute gonorrhoea many alternatives to penicillin have been tried. An ideal antigonorrhoeal substance would have the following properties: it should be effective for single-session

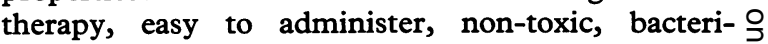
cidal but not treponemicidal, and non-allergic. Rif- $\rightarrow$ ampicin seems to satisfy these criteria, although its

TABLE I Results of treatment

\begin{tabular}{|c|c|c|c|}
\hline \multirow{2}{*}{$\begin{array}{l}\text { Treatment } \\
\text { Sex }\end{array}$} & \multicolumn{3}{|c|}{ Rifampicin $900 \mathrm{mg}$. by mouth } \\
\hline & Male & Female & Total \\
\hline $\begin{array}{l}\text { Total no. of cases } \\
\text { No. followed up } \\
\text { No. cured } \\
\text { Re-infections } \\
\text { Failures } \\
\text { Non-gonococcal infections }\end{array}$ & $\begin{array}{r}76 \\
62 \\
46 \\
5 \\
7 \\
4\end{array}$ & $\begin{array}{r}42 \\
36 \\
32 \\
1 \\
3 \\
0\end{array}$ & $\begin{array}{r}118 \\
98 \\
78 \\
6 \\
10 \\
4\end{array}$ \\
\hline Percentage failures & $13 \cdot 2$ & $8 \cdot 6$ & $11 \cdot 3$ \\
\hline
\end{tabular}

\begin{tabular}{|c|c|c|}
\hline Male & Female & Total \\
\hline $\begin{array}{r}59 \\
45 \\
40 \\
4 \\
0 \\
1\end{array}$ & $\begin{array}{r}54 \\
43 \\
38 \\
4 \\
0 \\
1\end{array}$ & $\begin{array}{r}113 \\
88 \\
78 \\
8 \\
0 \\
2\end{array}$ \\
\hline 0 & 0 & 0 \\
\hline
\end{tabular}

ॠWith three cultures for women and two for men 
effectiveness is not on a level with penicillin at the dose used in the control group, which, when administered with probenecid, can be expected to produce a cure rate of almost 100 per cent. In many parts of the world gonococcal strains are proving increasingly resistant to penicillin, and increasing dosages of penicillin used in recent years do not indicate a final solution to the problem, but should be an incentive to search for alternatives.

Rifampicin is a good alternative to penicillin in patients who are hypersensitive to penicillin, or in cases in which it is important to avoid masking syphilis. As rifampicin is also used in the treatment of tuberculosis, considerations beyond the sphere of venereology may have to be taken into account.

\section{Summary}

118 patients ( 76 men and 42 women) with gonorrhoea were treated with a single oral dose of $900 \mathrm{mg}$. Rifampicin (Rimactane $₫$ (CIBA)); of the 98 patients followed up (62 men and 36 women), 86.8 and $91 \cdot 4$ per cent. respectively, were cured with this treatment as compared with 100 per cent. of a control group treated with $1 \mathrm{~g}$. probenecid and a single injection of 5 m.u. sodium penicillin G. Rifampicin is well tolerated, and only one case of vomiting immediately after administration of the tablet was recorded, but this patient received a second dose of rifampicin without any side-effects and was cured. We have found that rifampicin is a useful alternative to penicillin in cases in which the latter cannot be administered.

\section{References}

ARYa, O. P., RAo, S. K., and Nnochiri, E. (1971) Brit. F. vener. Dis., 47, 184

BECKER, Y., and ZAKAY-Rones, Z. (1969) Nature (Lond.), 222, 851
Califano, A., and Tagliavini, R. (1968) Minerva Derm. 43, 516

Ciaula, V., and Rantuccio, F. (1968) Rass. derin sif., 21, 6

FugA, G. C. (1968) Paper presented at Rimactane-Symposium, CIBA, Basel

HartmanN, G., Honikel, K. O., Knüsel, F., and NüzsCh, J. (1967) Biochim. biophys. Acta, 145, 843

Heller, E., Argaman, M., Levy, H., and Goldblum, N. (1969) Nature (Lond.), 222, 273

Lepetit Pharmaceuticals (1968) 'Rifampicin-A Handbook'. Slough

Phillips, I., Rimmer, D., Ridley, M., LynN, R., and WARREN, C. (1970) Lancet, 1, 263

ReYN, A., and Bentzon, M. W. (1969) Brit. F. vener. Dis., 45, 223

Subak-Sharpe, J. H., Timbury, M. C., and Williams, J. F. (1969) Nature (Lond.), 222, 341

Wehrli, W., Nürsch, J., KNüsel, F., and Staehelin, $M$. (1968) Biochim. biophys. Acta, 157, 215

Willcox, R. R., MORRISON, G. D., and Cobbold, R. J. (1970) Brit. F. vener. Dis., 46, 145

\section{Traitement de la gonococie aigüe par une dose} orale de rifampicin

SOMMAIRE

118 malades (76 hommes et 42 femmes) atteints de gonococcie ont été traités par une dose orale unique de $900 \mathrm{mg}$. de rifampicin (Rimactane $₫$, Ciba). Sur les 98 malades suivis ( 62 hommes et 36 femmes), 86,8 et 91,4 pour cent furant guéris, respectivement, par ce traitement; ceci contre 100 pour 100 dans un groupe témoin traité par l'association de $1 \mathrm{~g}$. de probénécide et d'une injection unique de $5 \mathrm{~m} . \mathrm{u}$. de pénicilline sodique. La rifampicin a été bien toléréé, il y a eu un seul cas de vomissement signalé après l'administration d'un comprimé, mais ce malade reçut une seconde dose de rifampicin sans aucun trouble et fut guéri. Nous trouvons que la rifampicin est un traitement pouvant remplacer la pénicilline dans les cas où celle-ci ne peut pas être prescrite. 